\title{
Loss of primary texture and geochemical signatures in speleothems due to diagenesis: Evidences from Castañar Cave, Spain
}

\author{
Rebeca Martín-García *, Ana M. Alonso-Zarza, Andrea Martín-Pérez \\ Departamento de Pebrologia y Geoquinica-Instituto de Geologia Economica, Universidad Compluterse de Madrid-CSIC, Madrid, 28040, 5pain.
}

Keywords:

Meteoric diagenesis

Speleothems

Isotope geochemistry

Palaeoclimate

Castañar cave

\begin{abstract}
A B S T R A C T
Geochemical signals from speleothems are commonly used in the investigation of palaeoenvironments. In most cases, however, little attention is paid to whether or not these signals are primary or altered lyy diagenesis. The speleothems of the Castañar Cave (Câceres, Spain), which are initially formed of calcite or aragonite, have undergone a variety of meteoric diagenetic processes such as micritization and neomorphism (inversion), that collectively modify their primary features (textures, mineralogy, geochemical signals). The mean ${ }^{13} \mathrm{C}$ and $8^{18} \mathrm{O}$ values of the aragonites in the cave are -8.66 and -4.64 respectively, whereas the primary calcites have mean $\delta^{13} \mathrm{C}$ and $\delta^{19} \mathrm{O}$ values of -9.99 and -5.77 , respectively. Following the diagenetic process of micritization, the aragonite isotopic signals averaged $-7.63{ }^{13} \mathrm{C}$ and $-4.740^{19} \mathrm{O}$ and the calcite micrite signals $-9.53 \delta^{13} \mathrm{C}$ and $-5.21 \delta^{18} \mathrm{O}$. Where inversion took place, some secondary calcites after the aragonite show preserved aragonite, whereas others do not. The secondary calcites without aragonite relics show isotopic values slightly higher than those of the primary calcite due to the inheritance of the aragonite signal. Where aragonite relics are preserved, the isotopic signatures are very similar to those of the aragonite micrite.

In addition, the stable isotopic values and $\mathrm{Sr}$ and $\mathrm{Mg}$ contents of the speleothems became also modified by micritization and/or inversion. These diagenetic processes were driven by the changes in composition of the cave waters over time and space, but also, in the case of aragonite, by its initial unstable mineralogy. The present results highlight how important diagenesis is in caves and how the initial features of cave minerals may be lost. These changes alter the geochemical signals shown by speleotheins, which may have an impact on the interpretation of the results obtained in palaeoenvironnnental studies.
\end{abstract}

\section{Introduction}

The stable isotope values and trace element contents of speleothems are commonly used to infer the conditions of Quaternary palaeoclimate (McDermott, 2004; Fairchild et al., 2006) under the assumption that their constituent minerals have undergone no diagenetic modification. There is the potential, however, that various meteoric diagenetic processes can significantly modify the original precipitates. For example, Hill and Forti (1997) and Rowling (2004) indicated that aragonite, which is common in caves, may change its crystal structure to that of calcite. Only a few studies, however, have taken such diagenetic processes into account, even though Frisia et al. (2002) and Woo and Choi (2006) pointed out the importance of determining if the signals being recorded are primary or if they have been modified by diagenetic processes such as micritization and inversion.

In marine sedimentary environments, micritization has usually been related to the action of microorganisms that affect allochems in the shallow marine realm (Alexanderson, 1972; Brand, 1989; Reid and Macintyre, 1998; Reid and Macintyre, 2000). This process, however, has also been ascribed to diagenetic dissolution with no organic implications as described by Neugebauer (1978) in crinoids from the Upper Cretaceous of Kansas. Abiotic micritization has also been studied in cave substrates (Jones and Kahle, 1995); in cave pool deposits (Jones, 1988), and in speleothems associated to condensation corrosion over the surface (Auler and Smart, 2004).

Studies of aragonite-to-calcite transformations have been usually carried out on marine shells; for example, Maliva (1998) studied this process in aragonitic molluscs from the Purbeck Group of southern England and Maliva et al. (2000) examined skeletal fragments of Plio-Pleistocene limestones and sandstones from Hollywood, Florida. Little attention, however, has been paid to neomorphism of speleothems apart from Frisia et al. (2002), BarMatthews et al. (1991), and Woo and Choi (2006). These studies 
stressed the importance of neomorphism in caves and the need to undertake detailed petrographic and geochemical studies before using speleothems as palaeoambiental archives.

The present study characterises the diagenesis of aragonite and calcite under meteoric vadose conditions in Castañar Cave, Spain (Fig. 1). This study shows that these digenetic processes occur in relatively stable caves, provide criteria for their recognition, and discuss their driving mechanisms. In doing so we provide a better understanding of the study of early diagenesis in caves.

\section{Terminology}

The meaning and uses of the term micrite are controversial. Friedman (1985), for example, gave genetic and descriptive connotations to the term micrite whereas Milliman et al. (1985) used it as a descriptive term with no genetic implications. In this paper micrite is used as a descriptive term that is independent of interpretation or

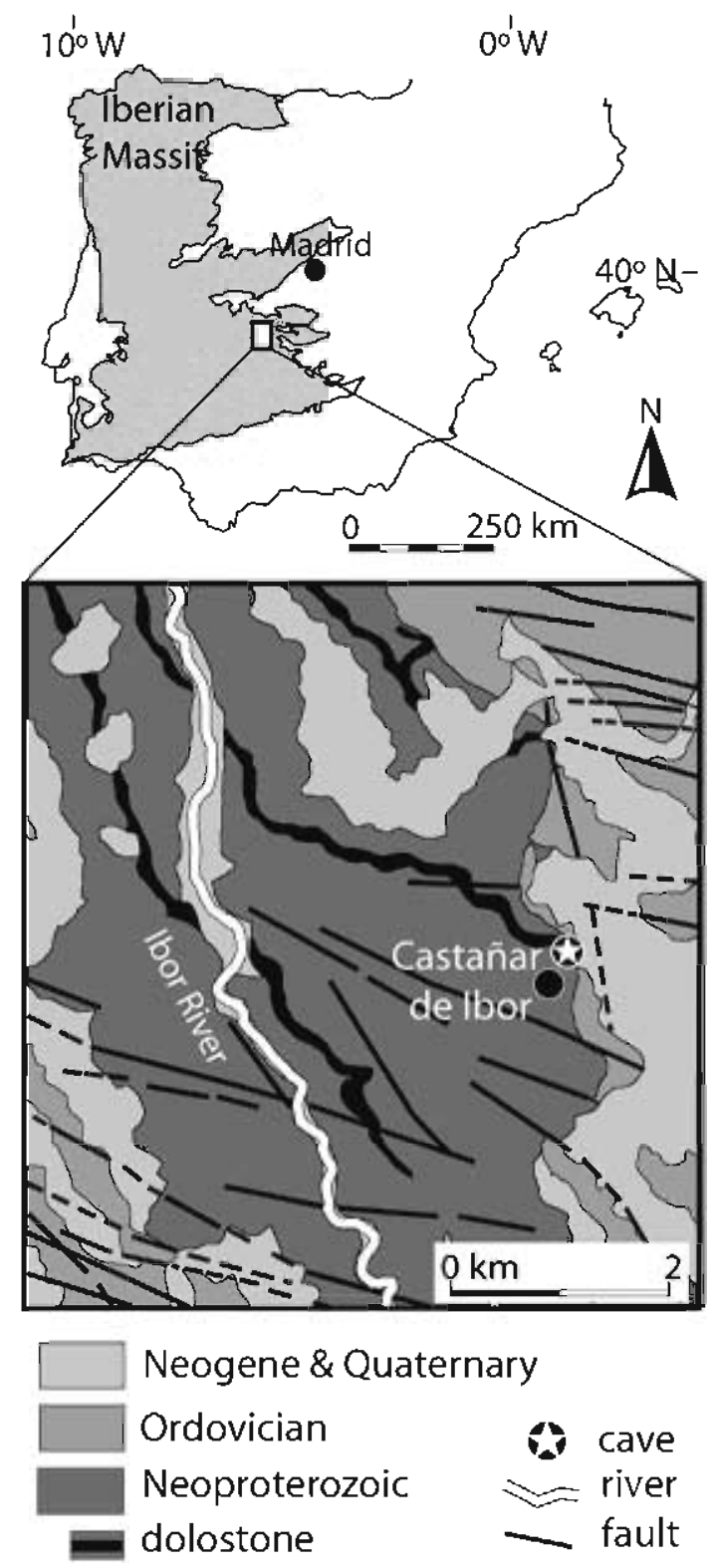

Fig. 1. Location of Castañar Cave. General situation within the Iberian Massif and geologic map of the study area showing the location of the cave mineralogy. Thus, it follows the criteria of Milliman et al. (1985) and Jones et al. (1995) who used micrite to describe carbonate particles less than $4 \mu \mathrm{m}$ long.

Even though the term micrite comes from the contraction of "microcrystalline calcite" (Folk, 1959), the term aragonite micrite (aragonite with micritic crystal size) has been widely used (e.g. Friedman, 1964; Alexanderson, 1972; Pedone and Ddickson, 2000; Dix et al., 2005) to refer to aragonite particles less than $4 \mu \mathrm{m}$ long.

Residual micrite refers to micrite formed by the biogenic or abiogenic breakdown of a calcite substrate (Kobluk and Risk, 1977; Jones, 1995 et al.). If this residue stays close to its place of origin it is called endogenetic micrite (Jones and Kahle, 1995), whereas exogenetic micrite is used to describe micrite founded far from the place it was formed.

Neomorphism is an inclusive term to define isocompositional and replacive processes such as recrystallization and inversion (transformation of one polymorph into another) (Folk, 1965).

\section{Geological setting}

Castaniar Cave is located in the southern part of the Iberian Massif. The cave is hosted in the Neoproterozoic rocks that form the core of the Ibor anticline (Fig. 1). These rocks are shales and greywackes with interbedded dolostones and magnesites (Alonso-Zarza et al., 2005). Dissolution of the dolomitic and magnesitic beds and the extensive weathering of the shales and greywackes promoted collapse that created and enlarged the cave. The dissolution of dolomite and magnesite also determines the composition of the cave waters, which are rich in $\mathrm{Mg}$ with $\mathrm{Ca} / \mathrm{Mg}$ ratios of 0.5 to 1.0 . These waters are usually saturated with respect to calcite, dolomite, and aragonite (SánchezMoral et al., 2006). The mean temperature of the cave is $17^{\circ} \mathrm{C}$ (constant year round) and the relative humidity of the air is close to 100\% (Sánchez-Moral et al., 2006).

The speleothems of the cave vary in their mineralogy and morphology. The dominant minerals are aragonite and calcite, but $\mathrm{Mg}$-rich carbonates such as dolomite, huntite, magnesite and hydromagnesite are found locally, forming moon-milk deposits and crusts (Alonso-Zarza and Martin-Pérez, 2008). Aragonite fans coalesce to form the most common morphologies, which are frostworks, helictites, anthodites, stalactites, stalagmites, draperies, and flowstones.

\section{Materials and methods}

Conventional optical petrography studies were performed on 70 thin sections taken from 60 speleothems, including stalactites, stalagmites, soda straws, draperies, flowstones, and pool floors. Due to their fragility, these samples were submerged in a resin containing Epofer EX 401 and Epofer E 432 in a vacuum system.

Scanning electron microscopy was performed on 13 gold-coated samples. Observations were made using a JEOL 6400 electron microscope working at $20 \mathrm{kV}$ and with a resolution of $35 \mathrm{~A}$. Secondary electron and backscattering detectors were used together with an X-ray detector system to obtain semiquantitative compositions.

The $\mathrm{Mg}, \mathrm{Sr}, \mathrm{Fe}$, and $\mathrm{Mn}$ contents of the different minerals in selected polished samples were obtained using an electronic microprobe (JEOL JXA $8900 \mathrm{M}$ ) operating at $15 \mathrm{kV}$ and $20 \mathrm{nA}$ and employing an electron beam diameter of $5 \mu \mathrm{m}$. The standards used are described by Jarosewich et al. (1980) and were provided by the Smithsonian Institute, Washington, USA. 50 powdered samples from 18 speleothems (selected from the zones in which the diagenetic processes were best preserved) were mineralogically characterised using a Philips PW-1710 X-ray diffraction (XRD) system operating at $40 \mathrm{kV}$ and $30 \mathrm{~mA}$, and employing monochromated CuK $\alpha$ radiation. XRD spectra were obtained from 2 to $66^{\circ} 2 \theta$. Crystals $<2 \mathrm{~mm}$ in diameter could not be isolated. 
The $\delta^{13} \mathrm{C}$ and $\delta^{18} \mathrm{O}$ values of these 50 powdered samples were later analysed at the Stable Isotope Laboratory, Salamanca University (following reaction with $100 \%$ phosphoric acid), using a SIRA series II spectrometer from VG Isotech. The experimental error for carbonates $\left(\delta^{13} \mathrm{C}\right.$ and $\left.\delta^{18} \mathrm{O}\right)$ was $0.1 \%$. A small-drill $(0.5 \mathrm{~mm}$ in diameter $)$ was used to avoid mixtures of the different minerals and layers of the speleothems.

\section{Petrography and geochemistry of the speleothems}

\subsection{Primary speleothems}

The aragonite speleothems of the Castañar Cave are shiny and consist of acicular and transparent crystals with length-to-width ratio $\geq 6: 1$. These crystals have smooth surfaces and flat faces on the flanks (Fig. 2A). Both macro- and microscopically, the aragonite crystals are arranged in fans that cross and superimpose one another to form the speleothems. The aragonite contains little or no magnesium and the $\mathrm{Sr}$ content varies from 0.00 and $0.20 \mathrm{~mol} \%$, with a mean value of $0.108 \mathrm{~mol}_{\%} \mathrm{SrCO}_{3}$. The primary aragonite crystals have mean isotopic values of $-8.66 \delta^{13} \mathrm{C}$ and $-4.84 \delta^{18} \mathrm{O}$ (Table 1 ).

The calcite speleothems, which range in appearance from transparent to beige-transparent, are less shiny than their aragonite counterparts. They consist of palisade calcite crystals, $5 \mathrm{~mm}$ to $1 \mathrm{~cm}$ long, and $0.5 \mathrm{~mm}$ wide (Fig. 2B). Equant mosaics, with small crystals (0.1-1 mm wide), are also very common. Irrespective of the crystal
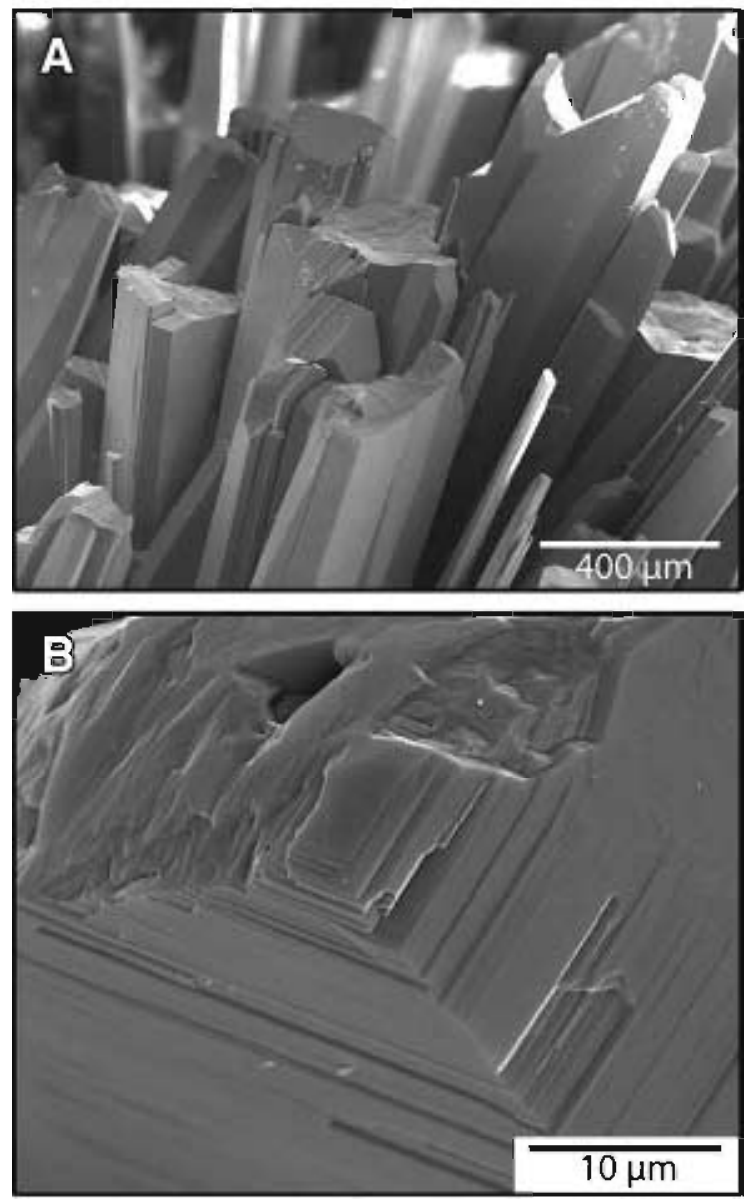

Fig. 2. SEM images of original crystals. (A) Aragonite fibres. The crystals show characteristic smooth surfaces. (B) Calcite crystal showing growing steps and flat faces.
Table 1

Isotopic and compositional mean values for the 50 analysed samples selected from stalactites, stalagmites and pool substrates at Castañar Cave on the basis of the different diagenetic processes taking place on them.

\begin{tabular}{|c|c|c|c|c|c|c|}
\hline & \multicolumn{4}{|l|}{ Calcite } & \multicolumn{2}{|c|}{ Aragonite } \\
\hline & \multirow[t]{2}{*}{ Primary } & \multirow[t]{2}{*}{ Micritized } & \multicolumn{2}{|l|}{ Secondary } & \multirow[t]{2}{*}{ Primary } & \multirow[t]{2}{*}{ Micritized } \\
\hline & & & $\begin{array}{l}\text { Without } \\
\text { aragonite } \\
\text { relics }\end{array}$ & $\begin{array}{l}\text { With } \\
\text { aragonite } \\
\text { relics }\end{array}$ & & \\
\hline$\delta^{13} C_{\mathrm{PDH}}$ & -9.99 & -9.53 & -9.55 & -8.51 & -8.66 & -7.63 \\
\hline$\delta^{1 \mathrm{a}} \mathrm{O}_{\mathrm{PDB}}$ & -5.77 & -5.21 & -5.13 & -5.18 & -4.84 & -4.74 \\
\hline
\end{tabular}

type, the calcite speleothems show well defined banding. In all cases the calcite speleothems have a low $\mathrm{Mg}$ content (up to $1.73 \mathrm{~mol} \%$ $\mathrm{MgCO}_{3}$ ) - but higher than that in the aragonite. Sr contents are very low, averaging $0.08 \mathrm{~mol}_{\%} \mathrm{SrCO}_{3}$. The primary calcites have a mean $\delta^{13} \mathrm{C}$ value of -9.99 and a mean $\delta^{18} \mathrm{O}$ value of -5.77 (Table 1 ).

\subsection{Micritization of the speleothems}

Polished hand samples of the micritized calcite and aragonite speleothems show a $1 \mathrm{~cm}$-thick, matt white, opaque external coating.
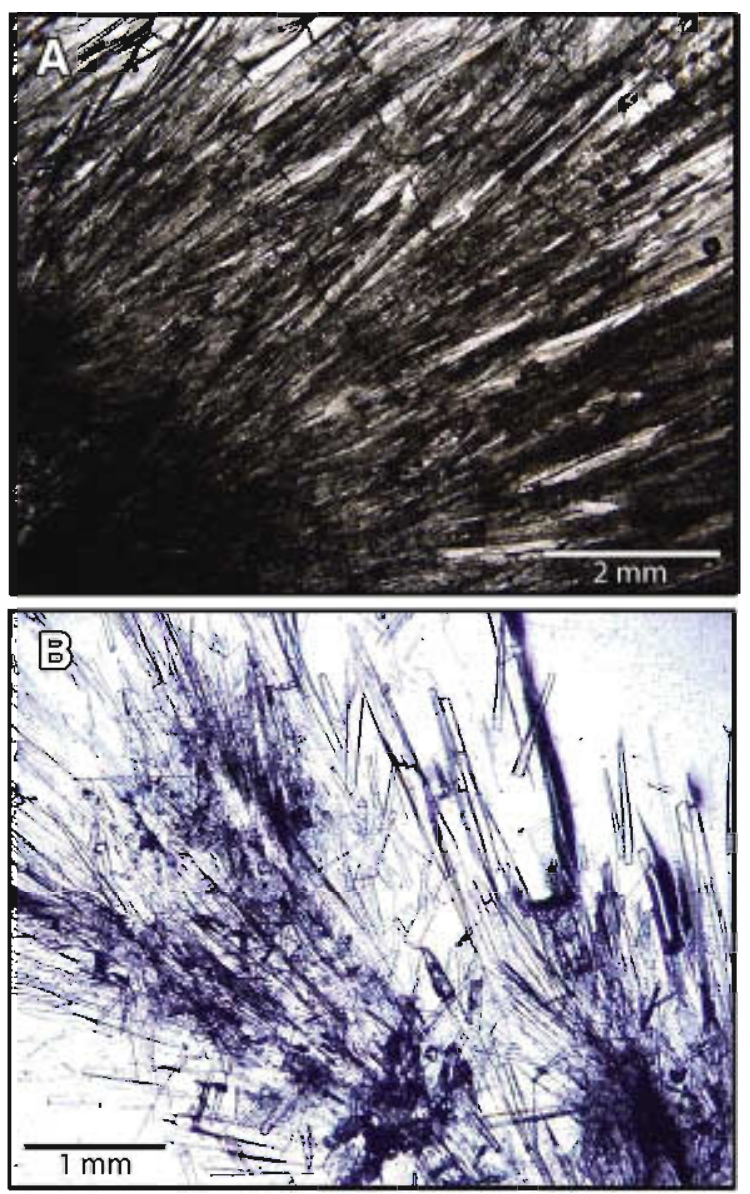

Fig. 3. Thin-section microphotographs with plain-polarized light. (A) Aragonite speleothem almost completely micritized. Micrite has a dark opaque colour whereas the primary crystals are transparent and clean. (B) Branching speleothem. Micrite appears especially in the nucleus of the fans forming dark opaque areas. (For interpretation of the references to colour in this figure legend, the reader is referred to the web version of this article.) 

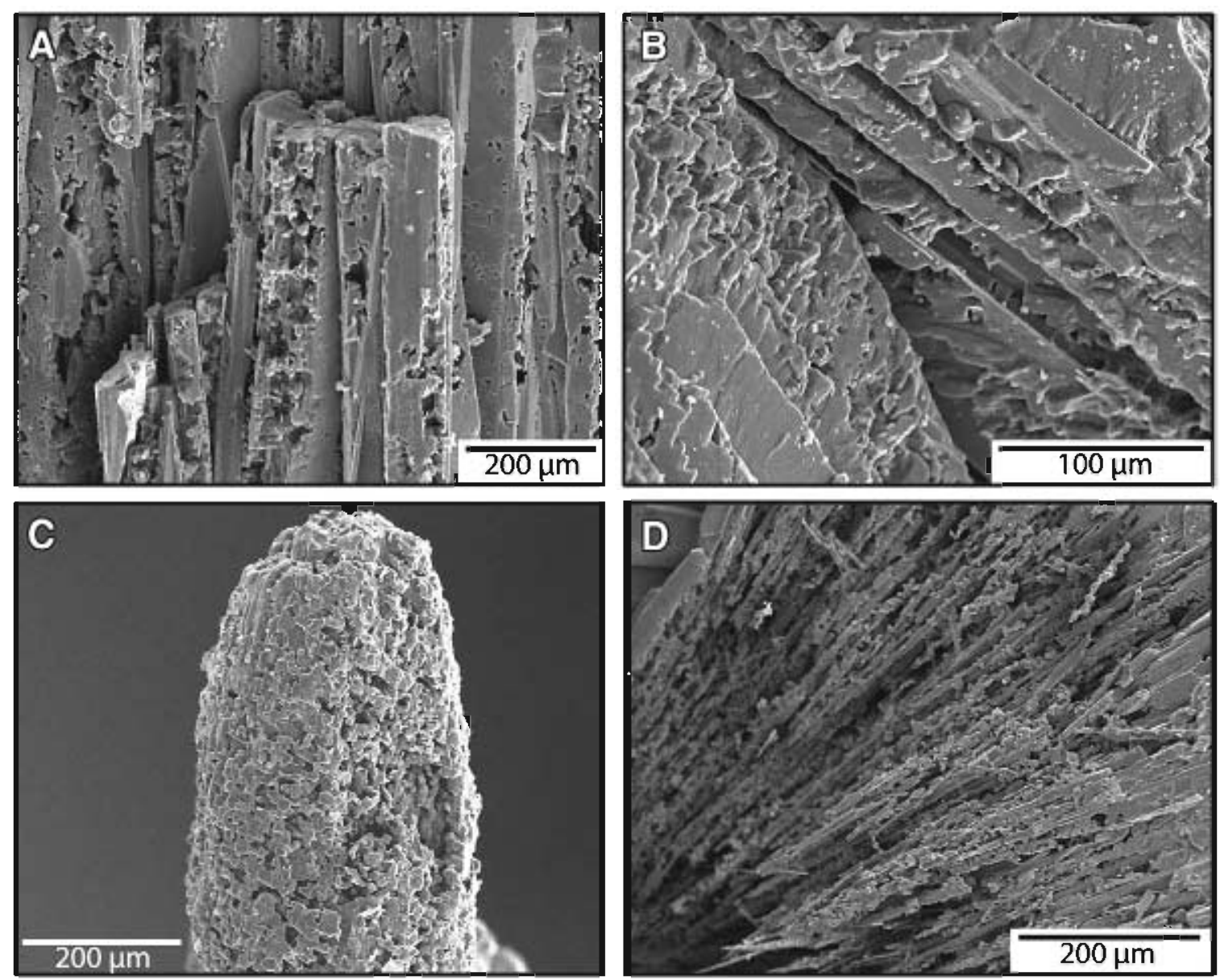

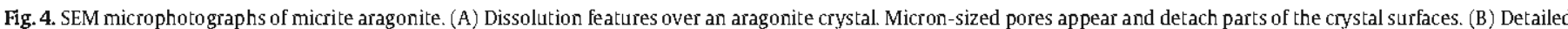

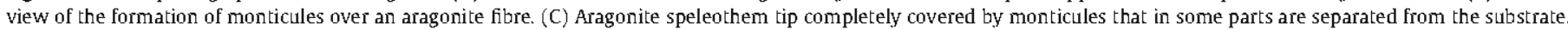
(D) Fan formed by aragonite needles that are partially dissolved and covered by a mass of residual micrite.

In the inner zone, micritization occurs as thin ( $m m$ ) concentric lines of similar characteristics to the surface coating.

In the case of aragonite, micrite appears as dark opaque structureless masses around the original crystals that are transparent and clean (Fig. 3A and B). At an advanced stage, none of the original crystals are left and the speleothems are formed entirely of micrite. The micritization process starts when the surfaces of the crystals are etched forming small pores $-2 \mu \mathrm{m}$ long, that coalesce to form larger ones (Fig. 4A and B). This process releases micron-sized parts of the crystals that stay on the surface and thereby start to form a mat of residual micrite (cf., Jones and Kahle, 1995) (Fig. 4C and D).

The isotopic signals of this aragonite micrite (recognised by DRX) are different to those obtained in the original crystals, especially for $\delta^{13} \mathrm{C}$ which shows a mean value of -7.63 . The mean value for $\delta^{18} \mathrm{O}$ is -4.74 . In the aragonite micrite the Sr content averages $0.13 \mathrm{~mol} \%$ $\mathrm{SrCO}_{3}$, higher than in the primary aragonite (Table 1 ).

The micrite associated with the calcite speleothems is similar to the micrite found on the aragonite speleothems. It appears as a disordered opaque mass over the original crystals that are usually corroded (Fig. 5A). In some cases, the calcite crystals present micritic lines following the growth bands inside the crystals (Fig. 5B). Under SEM, it is apparent that the primary crystal surfaces are smooth with no dissolution features such as those described by Jones (1987). On the other hand, the surface of the micritized crystals show small protuberances caused by the etching of the surface (Fig. 6A). This etching is followed by the formation of flakes (Fig. 6B) or monticules
(Fig. 6C). The flakes are about $10 \mu \mathrm{m}$ long and conserve the embossed surfaces of the crystals. Individual monticules in calcite surfaces consist on rounded to euhedral calcite particles detached from the background from which they are formed (Fig. 6C) that are left upstanding after the surrounding material has been dissolved. These small structures form the residual micrite (Fig. 6D).

Geochemical analysis revealed that in the same crystal, the micritized bands contain 1.2 times more $\mathrm{Mg}$ ( $1.05 \mathrm{~mol}^{\circ} \mathrm{MgCO}_{3}$ ) than the non-micritized bands. The Sr contents are as low as in the primary calcites. No differences are evident between the isotope values of the original calcite crystals $\left(-9.99 \delta^{13} \mathrm{C}\right.$ and $\left.-5.77 \delta^{18} \mathrm{O}\right)$ and the calcite micrite $\left(-9.53 \delta^{13} \mathrm{C}\right.$ and $-5.21 \delta^{18} \mathrm{O}$ ) (Table 1 ).

Dissolution and formation of residual micrite, formed of calcite or aragonite, is usually found on the surfaces of the speleothems that stay in contact with waters for the longest time, such as on the tips of the elongated speleothems where water drops accumulate before dripping, or in the surfaces of the larger ones (draperies, flowstones, etc.). In addition, the inner parts of the crystals can also be altered, especially in those crystals that have defects or show compositional zoning (Fig. 7A and B). In the case of calcite, which is commonly zoned, dissolution and micritization preferentially affect those bands with the highest $\mathrm{Mg}$ content. Morse and Arvidson (2002) also showed that the dissolution rate of calcites is controlled by the $\mathrm{Mg}$ content. All the micrite in this paper is considered as endogenetic, as demonstrated by its distribution, closely controlled by the dissolution of previous crystals. 

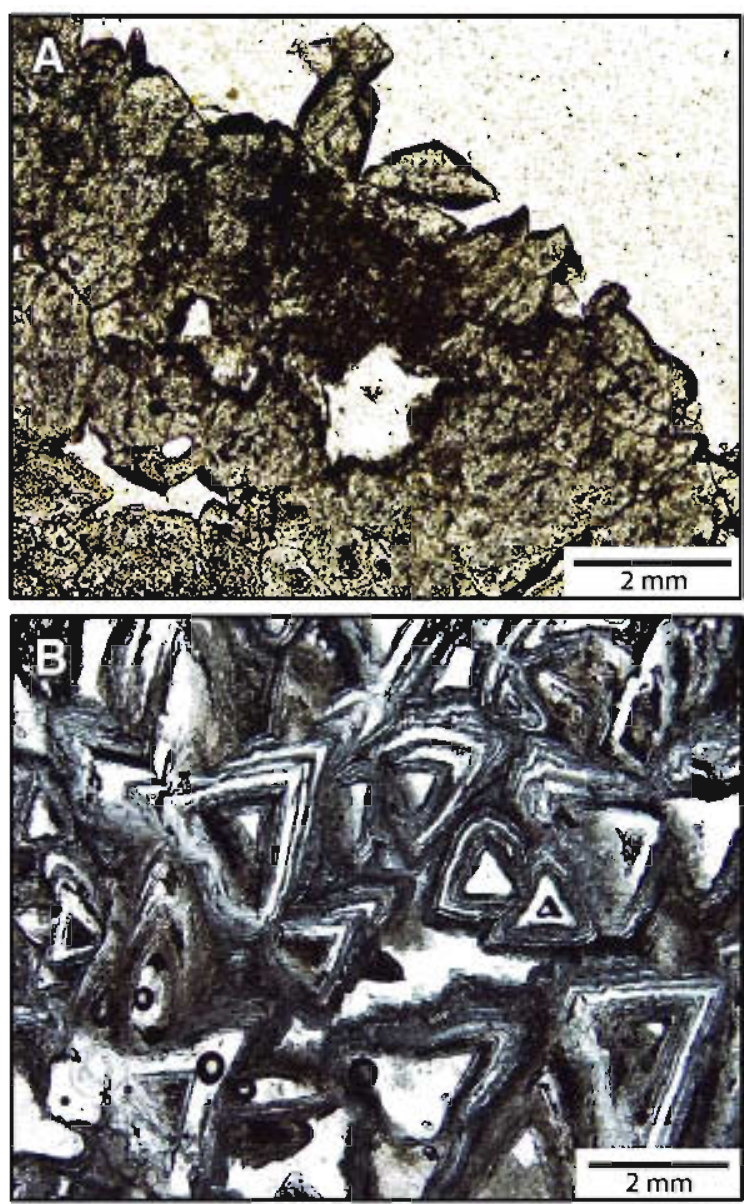

Fig. 5. Thin-section microphotographs with plain-polarized light. (A) Formation of micrite on calcite crystals. Dissolution disaggregates the crystals. (B) Micritization also occurs inside the crystals following their discontinuities.

\subsection{Inversion}

In hand sample, initially, aragonite speleothems show a shiny translucent white fibrous aspect that contrasts with the speleothems that have undergone inversion which are matt, brownish, and grainy due to the appearance of calcite mosaics.

Under the microscope, the aragonite speleothems that underwent inversion show a mosaic of equigranular calcite crystals that preserved either relic fibres of original aragonite or their textural ghosts (Fig. 8A to C). These fibres or ghosts can be followed from one calcite crystal to the next (Fig. 8A and B). Some inversion also took place in the micritized aragonite, as shown by the presence of darker lines (ghosts of micrite) in the calcite mosaics (Fig. 8B). Elsewhere, the secondary calcite after the aragonite crystals inherited the morphologies of the acicular aragonite crystals, being elongate and usually lacking relics (Fig. 8C).

SEM images show that small euhedral calcite crystals, $\sim 15 \mu \mathrm{m}$ long. grow on the surfaces of the acicular aragonite crystals (Fig. 9A). If these crystals continue to grow, they would eventually encase the aragonite fibres (Fig. 9B) and in some cases transform them into calcite (Fig. 9C). In other cases the fibres are not completely transformed and aragonite is preserved as relics inside the calcite crystals.

Isotope analyses show that the values of the secondary calcites with aragonite relic fibres are close to those of aragonite micrite. The mean $\delta^{13} \mathrm{C}$ value is -8.51 and the mean $\delta^{18} \mathrm{O}$ value is -5.18 . In secondary calcites lacking aragonite relics but containing ghosts ( $100 \%$ calcite), the values are close to those of primary calcite at -9.55 $\delta^{13} \mathrm{C}$ and $-5.13 \delta^{18} \mathrm{O}$, but with a slight shift towards the aragonite values. The $\mathrm{Mg}$ and $\mathrm{Sr}$ contents of the secondary calcites are similar to those of primary calcite (Table 1).

\section{Interpretation and discussion}

The diagenesis of the speleothems in the Castañar Cave is driven by the composition of its waters - which are temporally and spatially variable. Studies performed in recent years have shown that the cave's waters are always saturated with respect to calcite, but vary from saturated to undersaturated with respect to aragonite (SánchezMoral et al., 2006). Although calcite is the most common and stable polymorph of $\mathrm{CaCO}_{3}$, aragonite formation is favoured when the solutions present a high $\mathrm{Mg} / \mathrm{Ca}$ ratio and low supersaturations with respect to $\mathrm{CaCO}_{3}$ (De Choudens-Sánchez and González, 2009). Partially dehydrated $\mathrm{Mg}$ attaches to the surface on incipient calcite nuclei, inhibiting their growth (Berner, 1975) but favouring the precipitation of aragonite (Lippmann, 1973; Gutjahr et al., 1996a). The dissolution of the dolostones and magnesites of the host rock in Castaniar Cave, provides Mg-enriched solutions that favour the precipitation of aragonite.

Micritization has frequently been reported as a shallow marine diagenetic process involving the obliteration of the internal structure of carbonates via the formation of cryptocrystalline textures (Reid and Macintyre, 1998). Traditionally, the formation of micritic wraps over different skeletal components has been attributed to the action of microorganisms that bore and fill these components (Bathurst, 1966; Calvet, 1982). In contrast, dissolution has been considered the driving mechanism for micritization that takes place in the absence of organic influences (Neugebauer, 1978). This may be the case in the Castainar Cave, where the surfaces of the large crystals began to dissolve partially to form a mass of micron-sized crystals that partially or totally replaced the original components. In the case of aragonite, this micritization continued inwards randomly, following no preferred crystalline discontinuity. In the case of calcite, however, micritization preferentially advances along growth bands that have a high $\mathrm{Mg}$ content. Dissolution leading to micritization may be controlled by differences in the amount of $\mathrm{Mg}$ and $\mathrm{Sr}$ in the primary minerals. The fact that the micritized aragonite contains more Sr, and the calcite more $\mathrm{Mg}$ than their corresponding original minerals, suggests that differences with respect to stoichiometric composition may favour the preferential dissolution of these crystals (or zones within these crystals). Experiments on calcite and aragonite containing different amounts of $\mathrm{Mg}, \mathrm{Sr}$, and other trace elements have confirmed that the dissolution rates of both polymorphs increase with increasing quantities of these elements (Gutjahr et al., 1996b; Morse and Arvidson, 2002). The heavier $\delta^{13} \mathrm{C}$ values of the micritized aragonites compared to their primary counterparts are owed to the fact that $\mathrm{Ca}^{12} \mathrm{CO}_{3}$ is preferentially dissolved because of its greater mobility (Skidmore et al., 2004). In the Castañar Cave, micritization driven by dissolution occurs when the cave waters are close to undersaturation in either calcite or aragonite. Water with such properties can be found in different areas of the cave (Sánchez-Moral et al., 2006).

Most of the studied speleothems formed by inverted aragonite show a mosaic of calcite crystals with aragonite relics preserved within them. The inversion process appears to take place in two stages. In the first stage the initial porosity of the aragonite fans propitiates the nucleation of small crystals of calcite $(10 \mu \mathrm{m})$ along the aragonite fibres, which act as nuclei for the growth of larger calcite crystals. Large calcite crystals may grow to incorporate smaller calcite crystals and the aragonite fibres.

The transformation of one polymorph to another in the presence of a fluid takes place by the dissolution of the metastable one, in this case aragonite, and the precipitation of the stable phase, calcite (Perdikouri et al., 2008). A thin film of solution (from $100 \AA$ to $1 \mu \mathrm{m}$ 

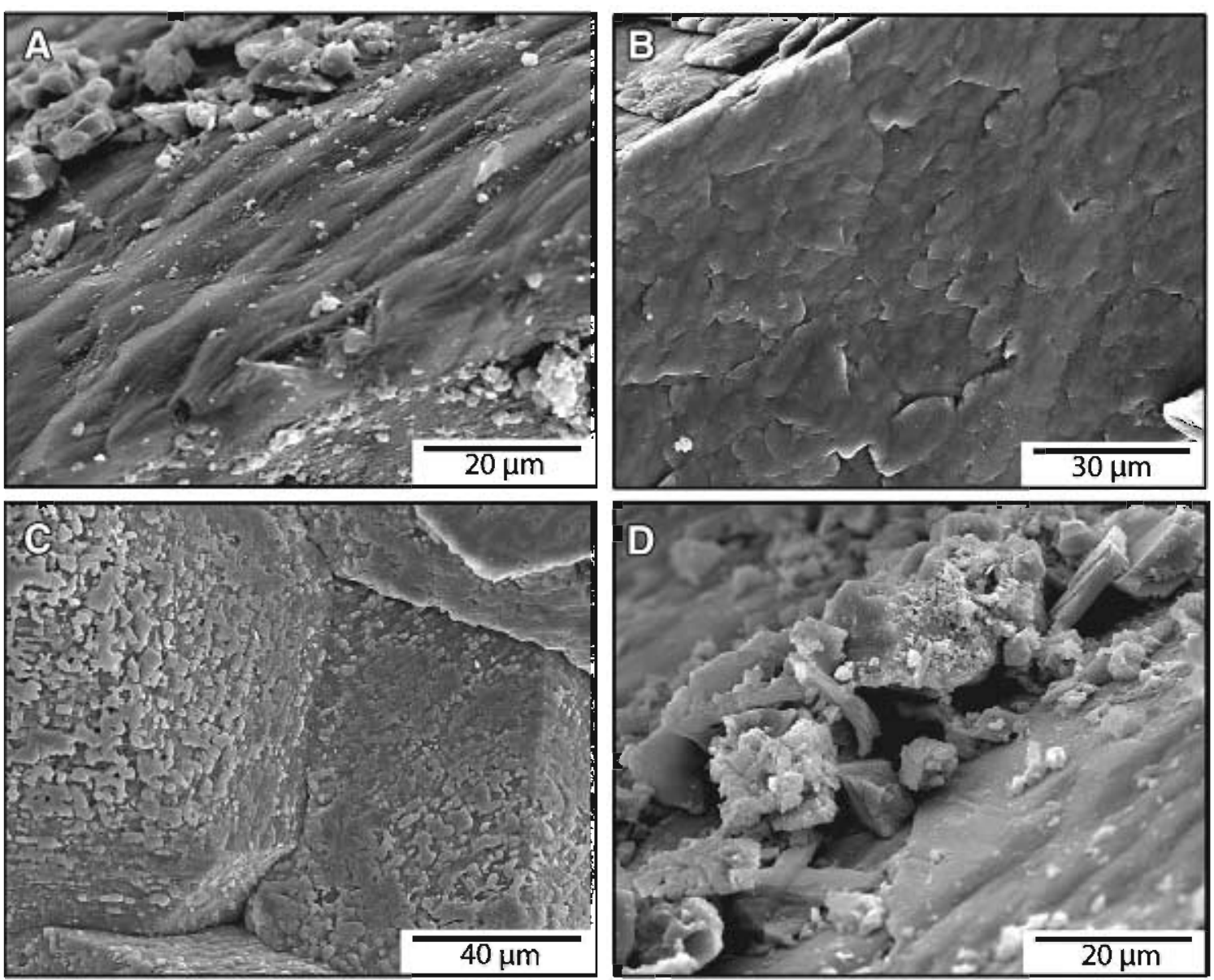

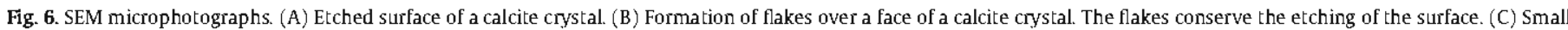
protuberances over a crystal which can lead to the formation of micrite by the detachment of the monticuly. (D) Detail of the formation of micrite by the breakage of a flake.

thick) propitiates the dissolution of aragonite, as the solution dissolves aragonite and precipitates calcite it becomes locally saturated in aragonite, leaving relics (Pingitore, 1976; Frisia et al., 2002). The incomplete inversion of the aragonite results in the preservation of aragonite crystals as solid inclusions within the calcite crystals. If the inversion is complete the relics are texturally but not mineralogically preserved (ghosts).

The overall inversion, which occurs at the microscale, takes place when waters are undersaturated in aragonite and oversaturated in calcite (Maliva et al., 2000; Frisia et al., 2002).

In this work it is seen that, as the aragonite relic content increases, the isotopic signals of the relic-bearing calcites become more similar to those of the aragonite micrite, averaging $-8.51 \delta^{13} \mathrm{C}$ and -5.18 $\delta^{18} \mathrm{O}$. This may indicate that inversion progresses easily on previously micritized aragonites, as indicated by Morse and Mackenzie (1990) and Perdikouri et al. (2008). Similarly, in aragonite shells of different ages, Maliva (1998) observed areas of small crystals of dissolved aragonite (which this author called the 'chalky zone') but with a simultaneous precipitation of calcite. In the present work secondary calcites without aragonite relics show isotopic values similar to those of the primary calcite, with a small trend towards those of aragonite. This indicates that these values are the consequence of the composition of the cave waters, with the precursor mineral having only a small influence.

Although microorganisms could play an important role in smallscale diagenetic processes in caves (Jones and Kahle, 1995; Boston et al., 2008), no evidence has been found in Castañar to prove their influence in both micritization and inversion.

\section{Implications for the interpretation of the geochemical signatures}

The main changes to be expected in the speleothems geochemical signatures result from the interaction of the primary minerals with the cave waters. These waters can be different depending mostly on the climatic conditions and on the time of interaction with the host rock. Thus the reaction of the primary minerals with heavier cave water inputs in more arid periods will result in a heavier isotope values than the initial ones. However, the problem is more complex because of the preference of the different minerals to incorporate heavier or lighter isotopes. In general any transformation of aragonite to calcite will result in lighter isotope values independently of the composition of the cave waters.

Therefore, before starting a palaeoclimate study, detailed petrographical studies must be done to reject the speleothem areas which have undergone any digenetic process and to focus the study into the primary minerals. This is important specially in caves were metastable minerals as aragonite, high magnesium calcite, etc., can be found. In addition, by the moment, the prediction of the exact pathways of the geochemical signatures through diagenesis is difficult because many factors interplay to vary the initial geochemical signals, such as: climate, initial mineralogy or time interacting with the host rock.

\section{Conclusions}

The diagenetic processes taking place in the Castañar Cave lead to important changes in the mineralogy, texture and geochemistry of its 

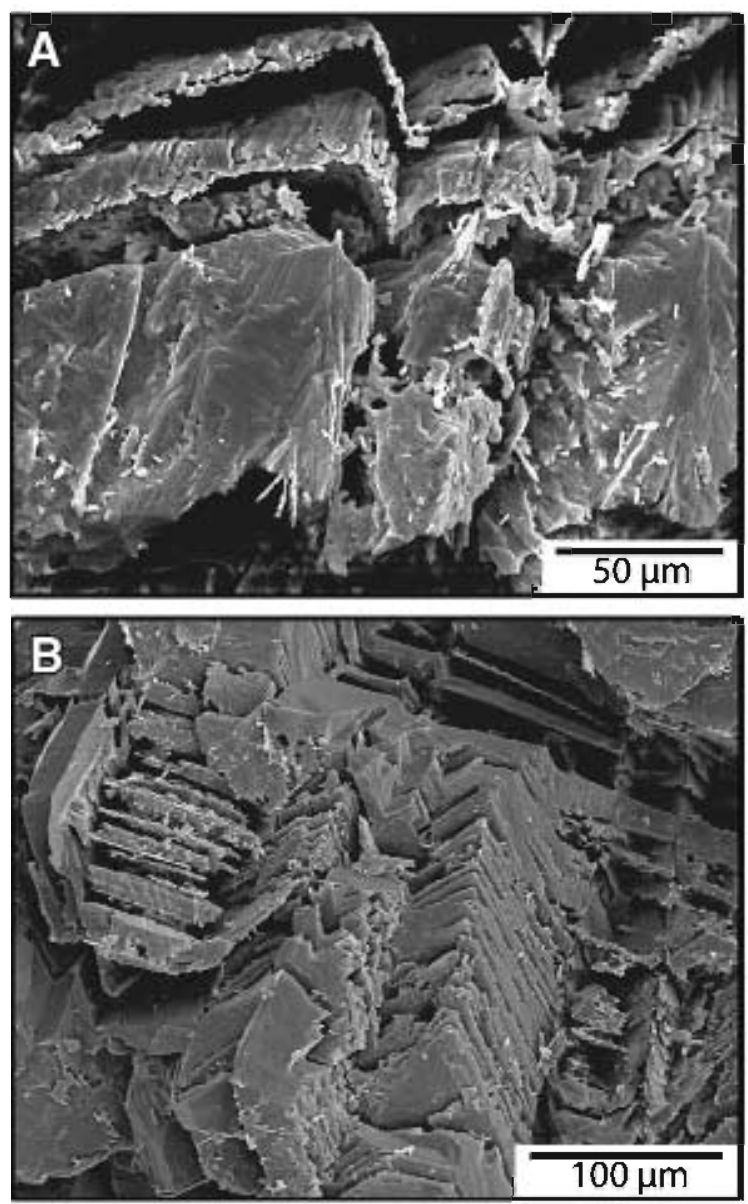

Fig. 7. SEM microphotographs. (A) Appearance of calcite crystals dissolved following crystalline discontinuities or differences in the composition of the growing bands of the crystals. (B) Detailed view of A

speleothems. Changes in the mineralogy of primary speleothems are due to the stabilization of aragonite, which transforms into calcite. This stabilization also results in the loss of the initial fibrous texture of the aragonite and the appearance of coarse and equant mosaics of calcite, with or without aragonite relics. The secondary calcites show no difference in the $\mathrm{Sr}$ and $\mathrm{Mg}$ contents comparing to the original calcites, but isotopically the secondary calcites are heavier in $\delta^{13} \mathrm{C}$ than their primary counterparts, especially those containing aragonite relics. The micritization of both aragonite and calcite appears to be driven by partial dissolution without the activity of organisms. The resultant texture consists of mosaics of micron-sized crystals. The isotopic and Sr contents of the micritized calcites are similar to the primary calcites, although their $\mathrm{Mg}$ contents are higher. Micritized aragonites show an increase in $\delta^{13} \mathrm{C}$ and $\mathrm{Sr}$.

These results highlight how important diagenesis is in caves, and how the initial features of primary cave minerals can be lost. Some of these diagenetic processes show striking similarities to those that occur in marine deposits, such as micritization and the stabilization of aragonite sediments, although with the differences discussed above. These changes may alter the palaeoenvironmental signals extracted from the analysis of speleothems - and therefore the way in which they should be interpreted. Certainly: 1) secondary calcites have $\delta^{13} \mathrm{C}$ and $\delta^{18} \mathrm{O}$ values different to those of their primary minerals; care must therefore be taken when identifying materials as primary; 2) the interpretation of palaeofluid characteristics should take into account that diagenesis also resets the major and trace element contents. In agreement with Frisia et al. (2000), the present results also suggests
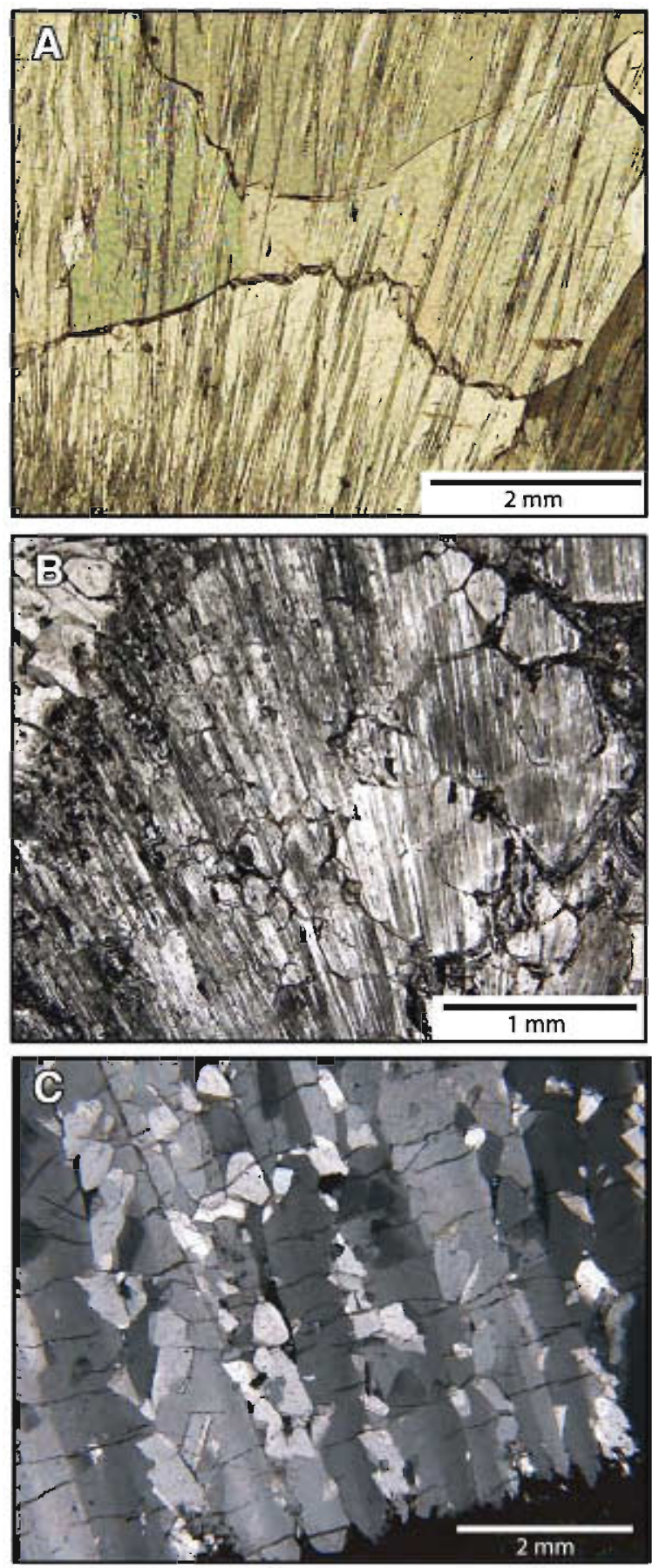

Fig. 8. Thin-section microphotographs. (A and C) Cross-polarized light. (B) Plainpolarized light. (A) Calcite mosaic with aragonite relics preserved. Note how the fibres can be followed from one calcite crystal to another. (B) Calcite mosaic with micritized aragonite relics inside. (C) Calcite crystals whit acicular morphology inherited from the aragonite. Small calcite crystals are found between the larger ones.

that if the analysis of calcite is used to extract physical and chemical data for palaeoenvironmental reconstructions or the calculation of growth rates, detailed microtextural (conventional petrography and SEM) studies must necessarily be performed.

\section{Acknowledgments}

This work received financial support from the Junta de Extremadura through FEOGA-ORIENTACION-FEDER funds, Project CGL-2008- 

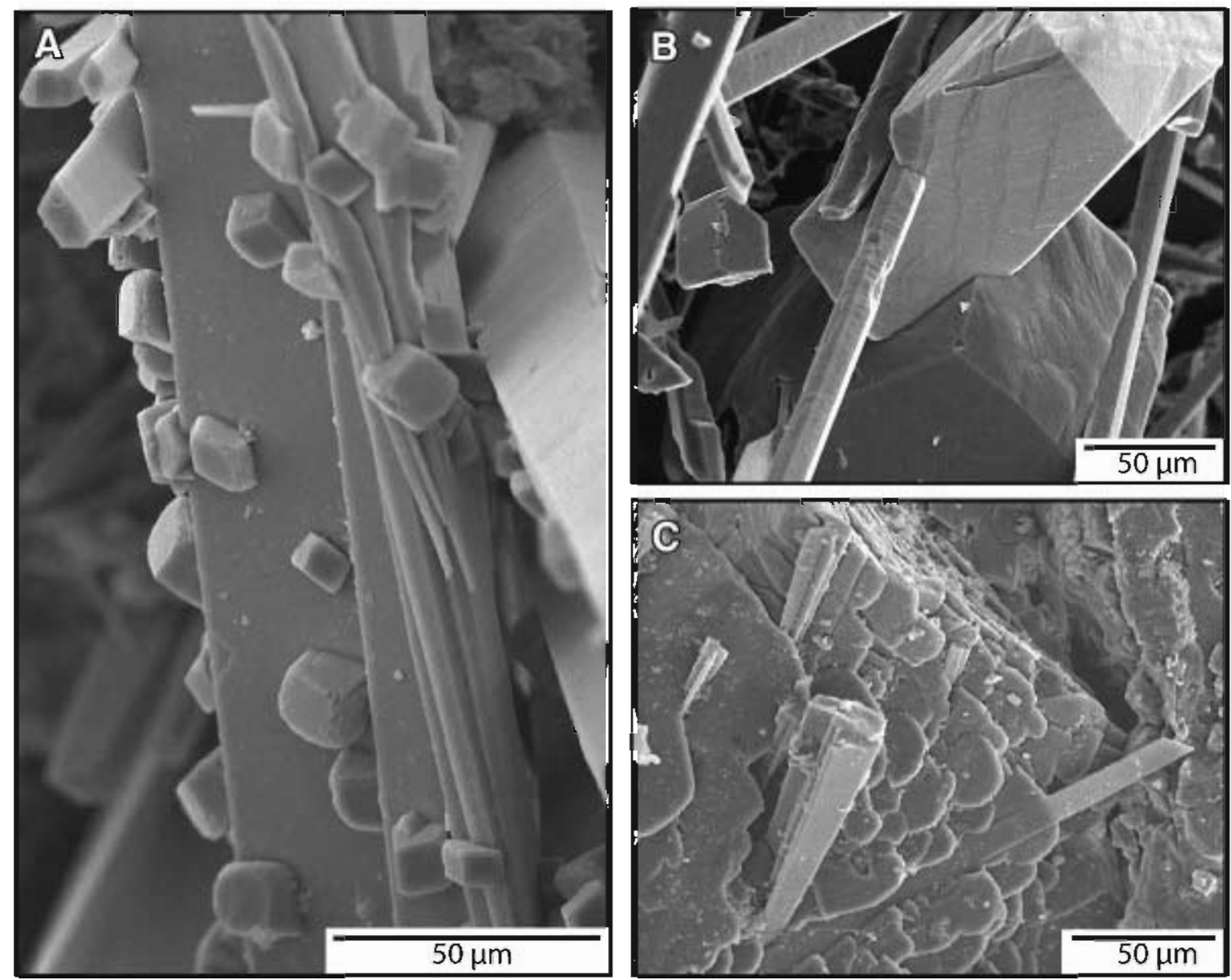

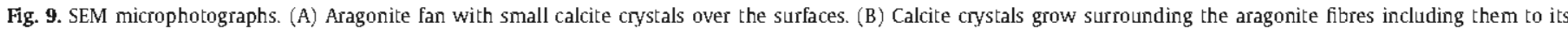
structure. (C) Relic fibres of aragonite included within a calcite mosaic.

05584-C02-02 from the MCINN and UCM-910404. B. Jones is gratefully aknowledged for the critical and constructive comments on the manuscript. I. Gil, P. Muñoz-Barco, E. Martínez and A. Blázquez are thanked for helpful discussion during field work. R. M-G was supported by a JAEPredoc-CSIC grant and A M-P by an I3P-CSIC grant.

\section{References}

Alexanderson, E.T., 1972. Micritization of carbonate particles: processes of precipitation and dissolution in modern shallow-marine sediments. Universitet Uppsala, Geologiska Institut Bulletin 7, 201-236.

Alonso-Zarza, A.M., Martín-Pérez, A., 2008. Dolomite in caves: recent dolomite formation in oxic, non-sulfate environments. Castañar Cave, Spain. Sedimentary Geolog 205, 160-164.

Alonso-Zarza, A.M., Gil-Peña, I., Martinez-Flores, E., Muñoz-Barco, P., 2005. La Clueva de Castañar. In: Muñoz-Barco, P., Martínez-Flores, E. (Eds.), Patrimonio geológico en Extremadura: geodiversidad y lugares de interés geológico. Dirección General de Medio Ambiente, Consejería de Agric ultura y Medio Ambiente. Junta de Extremadura Mêrílda.

Auler, A.S., Smart, P.L., 2004. Rates of condensation corrosion in speleothems of semiarid northeastern Brazil. Speleogenesis and Evolution of Karst Aquifers 2

Bar-Matthews, M., Matthews, A., Avalon, A., 1991. Environmental controls of speleothem mineralogy in a karstic dolomitic terrain (Soreq Cave, Israel). Journal of Geology 99, 189-207.

Bathurst, R.G.C, 1966. Boring algae, micrite envelopes and lithification of molluscan biosparites. Geology Journal 5, 15-32.

Berner, R.A., 1975. The role of magnesium in the crystal growth of calcite and aragonite from sea water. Geochimica et Cosmochimica Acta 39, 489-494

Brand, U., 1989. Aragonite-calcite transformation based on Pennsylvanian molluscs. GSA Bulletin 101, 377-390.

Boston, P., Spilde, M.N., Northup, D.E., Curry, M.C., Melim, L.A., Rosales-Lagarde, L., 2008. Microorganisms as speleogenetic agents: passive and active processes. 33rd International Geological Congress. Abstracts, 33, Abstract 1340156.
Calvet, F, 1982 Constructive micrite envelope developed in vadose continental en vironment in Pleis tocene eoliantes of Mallorca (Spain). Acta Geologica Hispanica 17 $169-178$

De Choudens-Sánchez, V., González, L.A., 2009. Calcite and aragonite precipitation under controlled instantaneous supersaturation: elucidating the role of $\mathrm{CaCO}_{3}$ saturation state and $\mathrm{Mg} / \mathrm{Ca}$ ratio on calcium cartonate polymorphism. Joumal of Sedimentary Research 79, 363-376.

Dix, G.R., James, N.P., Kyser, T.K., Bone, Y., Collins, LB., 2005. Genesis and dispersal of carbonate mud relative to Late Quaternary sea-level change along a distallysteepened carbonate ramp (Northwestern Shelf, Western Australia). Journal of Sedimentary Research 75, 665-678.

Fairchild, I.J., Smith, C.L, Baker, A., Fuller, L., Spötl, C, Mattey, D., McDermott, F., E.I.M.F. 2006. Modification and preservation of environmental signals in speleothems. Earth Science Reviews 75, 105-153.

Folk, R.L., 1959. Practical petrographic classification of limestones. AAPG Bulle tin 43, 1-38. Folk RL, 1965. Some aspects of recrystallization in ancient limestones. In: Pray, L.C. Murray, RC. (Eds. ), Dolomitization and limestone diagenesis - A symposium. Society of Economic Paleontologists and Mineralogists Special Publication, pp. 14-48.

Friedman, G.M., 1964. Early diagenesis and lithification in carbonate sediments. Joumal of Sedimentary Research 34, 777-813.

Friedman, G.M. 1985. The term micrite or micrite cement is a contradiction discussion of micritic cements in micotorings is not necessarily a shallow-water indicator. Journal of Sedimentary Petrology 55, 777

Frisia, S., Borsato, A., Fairchild, IJ., McDermott, F, 2000. Calcite fabrics, grow th mechanisms, and environments of formation in speleothems from the Italian Alps and Southwestern Ireland. Journal of Sedimentary Research 70, 1183-1196.

Frisia, S., Borsato, A., Fairchild, I.J., McDermott, F., Selmo, E.M., 2002. Aragonite-calcite relationships in speleothems (Grotte de Clamouse, France): environment, fabrics, and carbonate geochemistry. Joumal of Sedimentary Research 72, 687-699.

Gutjahr, A, Dabringhaus, H., Lacmann, R., 1996a. Studies of the growth and dissolution kinetics of the $\mathrm{CaCO}_{3}$ polymorphs calcite and aragonite I. Growth and dissolution rates in water. Journal of Crystal Growth 158, 296-309.

Gutiahr, A, Datringhaus, H., Lacmann, R., 1996b. Studies of the growth and dissolution kinetics of the $\mathrm{CaCO}_{3}$ polymorphs calcite and aragonite $I$. The influence of divalent cation additives on the growth and dissolution rates. Journal of Crystal Growth 158 , $310-315$. 
Hill, C.A, Forti, P., 1997. Cave minerals of the world. National Speleological Society, Huntsville.

Jarosewich, E.J., Nelen, J.A., Norberg, J.A., 1980. Reference samples for electron microprobe analysis. Geostandards News $4,43-47$

Jones, B., 1987. The alteration of sparry calcite crystals in a vadose setting, Grand Cayman Island. Canadian Journal of Earth Sciences 24, 2292-2304.

Jones, B., 1988. Calcite rafts, peloids, and micrite in cave deposits from Cayman Brac British West Indies. Canadian Journal of Earth Sciences 26, 654-664.

Jones, B., Kahle, C.F., 1995. Origin of endogenetic micrite in karst terrains: a case study from the Cayman Islands. Joumal of Sedimentary Research A65, 283-293.

Kobluk, D.R., Risk, M.J., 1977. Micritization and carbonate-grain binding by endolithic algae AAPG Bulletin 61, 1069-1082.

Lippmann, F., 1973. Sedimentary Cartonate Minerals. Springer-Verlag, Berlin.

Maliva, R.G., 1998. Skeletal aragonite neomorphism - quantitative modelling of a twowater diagenetic system. Sedimentary Geology $121,179-190$.

Maliva, R.G., Missimer, T.M., Dickson, J.A.D., 2000. Skeletal aragonite neomorphism in Plio-Pleistocene sandy limestones and sandstones, Hollywood, Florida, USA Sedimentary Geology 136, 147-154.

McDermott, F., 2004. Palaeo-climate reconstruction from stable isotope variations in speleothems: a review. Quaternary science Reviews 23, 901-918.

Milliman, J.D., Hook, J.A., Golubic, S., 1985. Meaning and usage of micrite cement and matrix - reply to discussion. Journal of Sedimentary Petrology 55, 777-784.

Morse, J.W., Arvidson, RS., 2002. The dissolution kinetics of major sedimentary carbonate minerals. Earth Science Reviews 58, 51-84

Morse, J.W., Mackenzie, F.T., 1990. Geochemistry of sedimentary carbonates. Elsevier Amsterdam. 707 pp.

Netugebatuer, J., 1978. Micritization of crinoids by diagenetic dissolution. Sedimentology $25,267-283$
Pedone, VA., Ddickson, JA.D, 2000. Replacement of aragonite by quasi-rhombohedral dolomite in a Late Pleistocene tufa mound, Great Salt Lake, Utah, U.S.A Journal of Sedimentary Research 70, 1152-1159.

Perdikouri, C., Kasioptas, A., Putnis, C.V., Putnis, A, 2008. The effect of fluid composition on the mechanism of the aragonite to calcite transition. Mineralogical Magazine 72 , $111-114$

Pingitore, N.E., 1976. Vadose and phreatic diagenesis; processes, products and their recognition in corals. Journal of Sedimentary Petrology 46, 985-1006.

Reid, R.P., Macintyre, I.G., 1998. Carbonate recrystal lization in shallow marine environments: a widespread diagenetic process forming micritized grains. Journal of Sedimentary Research 68,928-946 Part A

Reid, RP., Macintyre, I.G., 2000. Microtoring versus recrystallization: further insight into the micritization process. Journal of Sedimentary Research 70, 24-28.

Rowling, J., 2004. Studies on aragonite and its occurrence in caves, including New South Wales Caves. Journal and Proceedings of the Royal Society of New South Wales 137, $123-149$

Sánchez-Moral, S., Cuezva, S., Lario, J., Taborda-Duarte, M., 2006. Hydrochemistry of Karstic Waters in a Low-energy Cave (Castañar de Ibor, Spain). In: Durán, J.., Andreo, B., Carrasco, F. (Eds.), Karst, cambio climátion y aguas sub terr áneas. IGME, Madrid.

Skidmore, M. Sharp, M., Tranter, M., 2004. Kinetic isotopic fractionation during carbonate dissolution in laboratory experiments: implications for detection of microbial $\mathrm{CO}_{2}$ signatures using $0^{13} \mathrm{C}$-DIC. Geochimica et Cosmochimica Acta 68, $4309-4317$.

Woo, K.S., Choi, D.W., 2006. Calcitization of aragonite speleothems in limestone caves in Korea: diagenetic process in a semiclosed system. In: Harmon, R.S., Wicks, C. (Eds.) Perspectives on karst geomorphology, hydrology, and geochemistry. A tribute volume to Derek C. Ford and William B. White. GSA Special Paper. Geological Society of America, Boulder, Colorado. 